Fikrah: Jurnal Ilmu Aqidah dan Studi Keagamaan

issn 2354-6174 eissn 2476-9649

Tersedia online di: journal.iainkudus.ac.id/index.php/fikrah

Volume 9 Nomor 2 2021, (369-384)

DOI: $10.21043 /$ fikrah.v8i1.9365

\title{
Partisipasi Pesantren Luhur Al-Husna dalam Perdamaian Nasional: Studi tentang Peran Pesantren di Surabaya
}

\author{
Dwi Setianingsih \\ Universitas Islam Negeri Sunan Ampel Surabaya, Indonesia \\ dwisetia@uinsby.ac.id \\ M. Yusuf \\ Universitas Islam Negeri Sunan Ampel Surabaya, Indonesia \\ yusuf.much21@gmail.com
}

\begin{abstract}
This article aims to discuss and see further how big the role of the students of the Luhur Al-Husna Islamic Boarding School when facing plurality, both related to religious differences and certain sects. To answer these objectives, this article uses qualitative research with the type of phenomenology with analysis using the theory of Peter L. Berger and Thomas Luckman which includes externalization, objectification, and internalization. In instilling the value of peace in students, the Luhur Al-Husna Islamic Boarding School has two directions: namely, through the dawuh of Kiai Ali Maschan and through the customization ethics of the pesantren. Both of these are part of verbalization. While the teachings of the yellow book, have a secondary influence or role in cultivating the value of peace for Al-Husna students. These two things are external aspects in the pesantren that are understood and objectified into a general truth, that the Luhur Al-Husna Islamic Boarding School is a pesantren of "Peace." Then the value of peace is internalized in morals and behavior which leads to activities and taking roles in peace organizations and groups.
\end{abstract}

Keywords: Santri, pesantren, peace, social construction 


\begin{abstract}
Abstrak
Artikel ini bertujuan untuk mendialogkan dan melihat lebih jauh seberapa besar peran Pesantren Luhur Al-Husna ketika menghadapi pluralitas, dalam mewujudkan perdamaian nasional. Untuk menjawab tujuan tersebut, artikel ini menggunakan penelitian kualitatif dengan jenis fenomenologi dengan analisis menggunakan teori Peter L. Berger dan Thomas Luckman yang meliputi eksternalisasi, objektifikasi, dan internalisasi. Dalam menanamkan nilai perdamaian kepada santri, Pesantren Luhur Al-Husna mempunya dua arah: yakni, melalui dawuh dari Kiai Ali Maschan dan melalui etika pembiasaan pesantren. Kedua hal tersebut menjadi bagian daripada verbalisasi. Sedangkan ajaran kitab kuning, mempunyai pengaruh atau peranan sekunder bagi penanaman nilai perdamaian santri Al-Husna. Dua hal tersebut merupakan aspek eksternal di pesantren yang dipahami dan diobjektifikasi menjadi sebuah kebenaran umum, bahwa Pesantren Luhur Al-Husna ialah pesantren "Perdamaian." Kemudian nilai perdamaian terinternalisasi dalam moral dan laku yang berujung pada kegiatan dan pengambilan peran dalam organisasi dan kelompok perdamaian.
\end{abstract}

Kata kunci: Konstruksi sosial, pesantren, pluralitas, perdamaian nasional,

\title{
Pendahuluan
}

Pesantren sebagai lembaga pendidikan Islam indigenous di Indonesia yang memiliki ajaran "rahamatan lil'alamin" yaitu rahmat bagi alam semesta, mempunyai peran yang sangat mendesak dalam menciptakan perdamaian nasional di tengah keragaman suku, ras, dan agama. Indonesia, banyak orang yang menjulukinya sebagai negara majemuk. Hal ini terlihat dari banyaknya agama, kepercayaan, tradisi, kesenian, etnis, dan kultur. Hilderd Geertz dalam Balitbang Kemenag RI menggambarkan ragam kemajemukan tersebut dengan negara yang mempunyai lebih dari 300 etnis dengan budaya masing-masing, dan 250 jenis bahasa yang dipakai (Indonesia, 2012). Indonesia, juga dikatakan sebagai Islam sinketris, mendapatkan apresiasi yang luar biasa dari penduduk dunia (Kusumo, 2015). Hal ini dikarenakan suburnya nilai perdamaian di negara ini. Banyak spekulasi yang berkembang mengenai tumbuh suburnya perdamaian di Indonesia, salah satu penyebab yang tidak bisa dinafikan ialah peran pesantren sebagai agent of peace di bumi nusantara.

Pesantren merupakan lembaga pendidikan Islam yang sudah ada sejak ratusan tahun yang lalu (Usman, 2013). Eksisitensi keberadaan pesantren yang mengayomi bukan memusuhi, dalam artian membawa misi perdamaian, dikuatkan oleh penelitian Marthin van Bruinessen -seorang antropolog asal Belanda (Bruinessen, 1994). Di pesantren diajarkan ilmu dan nilai-nilai agama pada santri. Pengajaran tersebut biasanya berupa nonklasikal-bandongan atau wetonan, dan sorogan, dengan menggunakan kitab berbahasa Arab (Barton, 
2004). Namun, seiring berkembangnya zaman, pesantren juga menyesuaikan dalam bentuk kelas-kelas dan rombongan belajar (Hilmy, 2019). Umumnya para santri yang mengikuti pendidikan di pesantren harus tinggal di asrama dan meninggalkan kehidupan dengan keluarga masing-masing (Sidiq, 2013).

Pesantren sebagai tempat belajar agama juga sebagai lembaga pendidikan dengan ciri khasnya tersendiri (Rofiq, 2018). Ciri khas tersebut tergambar dari corak khas pribumi yang sudah ada sebelum kemerdekaan. Selain sebagai agent of peace, pendirian pesantren bertujuan sebagai sarana transformasi sosial -social transformation- bagi masyarakat. Keberadaan pesantren dianggap urgent di tengah arus globalisasi dan serbuan teknologi industri 4.0 (Hamid, 2017). Harapan besar datang dari masyarakat terhadap pesantren sebagai benteng nilai perdamaian di tengah modernisasi dunia. Urgensitas pesantren akan tercermin dari keterkaitan pesantren dengan masyarakat sekitar.

Pesantren Luhur Al-Husna adalah satu dari sekian pesantren di Indonesia yang menjaga marwah Islam yang damai dan santun. Hal ini tercermin dari misi yang dicanangkan, yaitu menciptakan insan kamil yang berilmu dan beramal saleh dalam mewujudkan Islam yang rahmatan li al'alamin (Pengurus, n.d.). Berbeda dengan golongan Islam kanan yang memiliki intepretasi pemahaman dalil-dalil keagamaan secara serampangan. Hal lain juga tergambar dari Pesantren Luhur Al-Husna, yakni selalu menanamkan nilai perdamaian dan toleransi kepada santri-santrinya. Dengan niatan agar menjadi cikal bakal nilai toleransi yang diterapkan di tengah masyarakat multikultural-Surabaya, sehingga tercipta kehidupan yang harmonis, rukun, dan sejahtera.

Pesantren Luhur Al-Husna juga memiliki keunikan tersendiri, yakni mengadakan kegiatan "Mondok Bareng." Kegiatan ini diinisiasi oleh persatuan Gereja Protestan Indonesia Bagian Barat -GPIB Surabaya dan bekerjasama dengan beberapa pengurus santri dari pihak pesantren. Namun, seunik apapun pesantren, tidak akan bisa berjalan jika salah satu unsur di dalamnya tidak terpenuhi. Salah satu unsur dari pesantren ialah santri yang tinggal di dalamnya (Muhakamurrohman, 2014). Besar dan majunya pesantren tergantung dari kualitas santri yang dihasilkan. Begitupula kegiatan-kegiatan perdamaian dan toleransi yang diadakan di Pesantren Luhur Al-Husna tidak akan bisa berjalan efektif tanpa ada dukungan santri yang menyertainya. Untuk itulah, artikel ini mencoba untuk mendialogkan dan melihat lebih jauh seberapa besar peran santri ketika menghadapi pluralitas, baik berkaitan 
dengan perbedaan agama dan perbedaan aliran tertentu. Penelitian-penelitian sebelumnya terkait Pesanren Luhur Al Husna adalah oleh Muhammad Hamdan Yuwafik dan Abdul Muhid dengan judul "Strategi Dakwah Pesantren Luhur AlHusna dalam Menjaga Toleransi Beragama di Kota Surabaya" (Yuwafik \& Muhid, 2020).

Adapun kesamaan penelitian ini dengan penelitian sebelumnya, yakni sama-sama membahas tentang Pesantren Luhur Al-Husna dan menggunakan setting penelitian lapangan dengan metode kualitatif. Bedanya, peneliti sebelumnya fokus mengetahui strategi dakwah yang dilaksanakan oleh Pesantren Luhur Al-Husna, sedangkan penulis ingin mencari tahu peran pesantren ketika menghadapi pluralitas. Sebenarnya dari dua penelitian tersebut yaitu antara strategi dakwah dan toleransi memiliki irisan dengan penelitian tentang perdamaian ini. Titik tekan dari irisan adalah strategi dakwah lebih pada "metode" atau "cara" berdakwah dalam membangun toleransi untuk mewujudkan perdamaian, karena toleransi merupakan kunci dari perdamaian. Sedang dalam penelitian perdamain meneliti lebih jauh tentang peran-peran keterlibatan pesantren secara konkrit dengan organisasi atau kelompok perdamaian yang ada di masyarakat dalam mewujudkan perdamaian nasional, seperti Forum Kerukunan Umat Beragama (FKUB), Youth Interfaith Peace Center (YIPC), Bord Game For Peace (BGFP) dan Global Peace Fondation (GPF).

\section{Metode}

Penelitian ini merupakan penelitian lapangan(field research) ini menggukan metode penelitian kualitatif dengan jenis penelitian fenomenologi. Pengumpulan data menggunakan observasi partisipatoris dan wawancara (McLeod, 2001; Moleong, 2015). Oleh karena itu, data primer dalam kajian ini meliputi aspek sosial dan moral Pesantren Luhur Al-Husna. Sumber-sumber sekunder meliputi kajian-kajian kepesantrenan. Setelah semua data terkumpul, akan dianalisis menggunakan teori Peter L. Berger dan Thomas Luckman yang meliputi eksternalisasi, objektifikasi, dan internalisasi (Berger \& Luckman, 1991).

\section{Biografi Pesantren Luhur Al-Husna}

Kata pesantren mempunyai padanan/muradlif dengan kata "pondok." Pondok mempunyai makna yang beragam, antara lain: rumah atau gubuk kecil, yang diambil dari serapan kata bahasa Arab "funduq" yang bermakna asrama. 
Selanjutnya, pondok berarti tempat untuk bermalam masyarakat pada umumnya. Hal ini mengakibatkan penamaan pada perumahan di suatu daerah diberi embel-embel kata "pondok" di depannya, seperti Perum Pondok Candra, Perum Pondok Jati, dan lain sebagainya. Sedangkan pengertian berbeda dikemukakan oleh Dlofier, bahwa pesantren bukan padanan dari pondok, melainkan serapan dari kata "santri" yang diberikan tambahan "pe" dan "an" pada awal dan akhir katanya, dan, memiliki arti tempat tinggal para santri (Dhofier, 2011). Untuk alasan itulah pendiri Pesantren Luhur Al-Husna tidak memakai kata "Pondok" dalam menamai pesantren yang beliau dirikan, hanya menamainya dengan "Pesantren Luhur Al-Husna" tanpa ada kata "Pondok" sebelumnya (Asror, 2020).

Pada mulanya, pesantren hanya berfungsi sebagai sarana islamisasi, namun, ternyata pesantren bisa menyatukan tiga unsur dalam pendidikan, yakni: ibadah, tabligh, dan mewujudkan kehidupan bermasyarakat (Dhofier, 2011). Pesantren juga mengalami perkembangan dinamis dari masa ke masa. Perubahan tersebut dapat dilihat dari sistim pendidikan yang dilaksanakan, hal ini karena pesantren mengamini perubahan zaman dan tuntutan yang berbeda dari masyarakat. Dilihat dari sistim tersebut setidaknya pesantren dibagi menjadi tiga macam, yaitu: salafiyah, khalafiyah, dan komperhensif. Sedangkan corak pesantren di era sekarang semakin beragam. Misalkan, adanya Pesantren Entrepreneuer Yayasan Al-Madinah Surabaya (Al-Madinah, n.d.), kemudian pesantren Entrepreneuer Mamba'ul Falah (Mambaul Falah, n.d.), dan Pesantren Entrepreneuer Qurani (PEO) di Bandung (Qurani, n.d.). Kesemua pesantren tersebut mencoba mengintegrasikan antara ajaran agama dan iptek. Bahkan, pesantren-pesantren tahfidz juga mengalami perkembangan, mereka melaksanakan pendidikan dengan mengembangkan fasilitas wajib bahasa - pesantren bilingual, seperti Pesantren Bilingual AlAmanah Junwangi Sidoarjo (Al-Amanah, 2021).

Dilihat dari sistem yang digunakan, Pesantren Luhur Al-Husna tergolong pesantren komperhensif, yakni penggabungan antara pengajian salaf dan sistem klasikal (kelas). Memang, Pesantren Luhur Al-Husna merupakan pesantren yang dikhususkan untuk mahasiswa yang sedang menempuh studi di Surabaya - rata-rata para santri tercatat sebagai mahasiswa UIN Sunan Ampel Surabaya, namun ada juga dari Universitas Islam Sunan Giri Surabaya, Universitas Nahdlatul Ulama Surabaya, IAI Al-Khazini Sidoarjo, dan Universitas Airlangga. Pesantren ini didirikan oleh Prof. Dr. KH. Ali Maschan Moesa, M.Si. pada bulan September 2001, atas wasiat dari orang 
tua dan guru-guru beliau yang memerintahkan untuk mendirikan lembaga guna memancarkan kebermanfaatan bagi umat banyak. Nama "Al-Husna" dipilih sebagai nama pesantren, memiliki tujuan agar selalu diselimuti segala kebaikan (Asror, 2020).

Pesantren Luhur Al-Husna terletak di Jl. Jemurwonosari Gg. Masjid No. 42, Kelurahan Jemurwonosari, Kecamatan Wonocolo, Kota Surabaya. Pesantren ini berjarak 100m dari jalan besar frontage Jl. Jend. A. Yani. Berdiri di atas tanah berukuran 15×30 m, terdiri dari tiga lantai dengan 31 kamar, masing-masing kamar berisi 4-6 santri. Lantai 3 pada bangunan Pesantren Luhur Al-Husna berupa aula yang digunakan setiap sore sebagai Taman Pendidikan Quran -TPQ- anak-anak kecil yang tinggal di sekitar pesantren. Bagian bawah dilengkapi dengan tempat parkir sepeda motor yang luas untuk para santri yang menetap.

Pesantren Luhur Al-Husna memiliki visi, yakni memberikan pendidikan dan pengajaran ilmu agama Islam (Islamic sciences) dan ilmu-ilmu sosial (social sciences). Visi tersebut dilengkapi dengan misi, yakni menciptakan insan kamil yang berilmu dan beramal saleh dengan istiqamah dan bertanggungjawab dalam mewujudkan Islam rahmatan li al- 'älamin. Kemudian diperluas dengan tujuan mencetak kader ulama, muballigh, pakar agama dan masyarakat yang mumpuni, tidak sempit wawasan, kaya ilmu dan amal salih, serta memiliki akhlaq yang terpuji -akhlāq al-karimah. Di samping itu, juga bertujuan untuk membina umat yang sadar akan agama, masyarakat, dan tanah air menurut ajaran ahlu al-shunnah wa al-jamā'ah, dijiwai pancasila dan diiringi ridha Allah SWT (Pengurus, n.d.).

\section{Ajaran Perdamaian: Antara Teks dan Verbal}

Ajaran di pesantren -baik konservatif maupun kontemporer- semuanya dapat dilihat dalam dua hal, yakni berdasarkan ajaran teks dan berdasarkan penuturan -verbal. Makna dari kata teks di sini ialah, merujuk kepada sumbersumber referensi kitab kuning, sedangkan makna dari kata verbal ialah, penuturan atau dawuh-dawuh kiai yang tidak ditulis, namun mengandung nilai pendidikan bagi para santri. Dalam hal ini sumber ajaran yang dirasa sangat mengena dan menjadi faktor utama dalam penyemaian perdamaian di Pesantren Luhur Al-Husna ialah dengan cara verbalisasi. Muhammad Iqbal Wardhana -santri senior sekaligus abdi yang sering membersamai Kiai Ali Maschan- menuturkan, bahwa dawuh yang spontan dilancarkan oleh Kiai Ali Maschan selalu terngiang dan menjadi sumber utama dalam setiap 
penyemaian perdamaian (Ningrum et al., 2018). Hal serupa juga diamini oleh M. Kholili Anam, domisioner ketua pengurus pesantren. Kholili mengatakan, bahwa dawuh Kiai Ali Maschan, khususnya, dan asatidz yang lain, umumnya, seperti sabda pandhita ratu yang wajib diamini kebenarannya. Bukan sekedar manis di bibir atau hanya perkataan biasa, namun menirukan perilaku kiai dan/atau asatidz sama halnya melakukan kesunahan di dalam syariat (Anam, 2018). Tidaklah heran, karena model Kiai sentris sudah terkenal sejak dahulu di kalangan pesantren. Kiai memang menjadi sosok yang keberadaannya sangat sentral, berimplikasi pada perkembangan pesantren, dan petuahnya wajib ditaati dan dijalakan. Greets berpendapat bahwa semua itu bisa terjadi karena hubungan kiai dan santri ialah hubungan patron-client (Geertz, 1992).

Sebagai contoh verbalisasi menjadi faktor dominan dalam penyemaian perdamaian di Pesantren Luhur Al-Husna ialah, bahwa Kiai Ali Maschan memberikan pemaknaan yang berbeda mengenai kata "Islam." Beliau berpendapat bahwa kata "Islam" bukan masdar -kata benda- dari fi'il madhi "salima" yang berarti aman, melainkan dari kata "aslama" yang berarti menyelamatkan. Jika Islam diambil dari kata salima, maka masdarnya berupa kata "salām," yang mana berimplikasi pada ketidakbutuhan sebuah objek fi' il lāzim. Sedangkan kata aslama, butuh akan objek untuk diselamatkan -fi' il muta'addiy. Untuk itu, jika mengaku beragama Islam, mengaku menjadi seorang muslim, seyogyanya para santri harus bersifat memberikan keselamatan, kedamaian, dan ketentraman bagi siapa saja dan apa saja -tidak hanya merujuk kepada orang, namun juga kepada alam sekitar (Asror, 2020). Lebih lanjut, Kiai Ali Maschan juga mendefinisikan nasionalisme pada pemahaman yang dirujuk dari kosa kata al-ummah, al-qoumiyyah, dan ashu'biyyah. Beliau menegaskan bahwa nasionalisme ialah keragaman dalam kebersamaan sebagai warga negara di suatu bangsa (Asror, 2020).

Kiai Ali Maschan juga sering mengutip hadis atau maqalah tentang pentingnya bersikap damai dan saling mengasihi satu sama lain, seperti: "Alulamā'u hum alladzina yandzurūna ummah bi 'aini al-rahmah" -ulama ialah mereka yang melihat umat dengan pandangan kasih sayang. Pada kesempatan yang lain, beliau juga mengutip: "Al-ikhtilāfu rahmah" -perbedaan pendapat para ulama ialah sebuah rahmat. Hadis atau maqalah tersebut beliau sampaikan di sela-sela pengajian kitab Tafsir Munir karangan Imam Nawawi Al-Bantani setiap selesai Shubuh (Moesa 2020) dan kitab Mauidlatul Mu'minin ringkasan kitab Ihya' Ulum al-Din setiap Kamis malam Jumat (Moesa, 2020), yang mana kedua kitab tersebut tidak ada fasal secara eksplisit membahas 
mengenai perdamaian, seperti al-ta'āwun, al-tasāmuh, al-ta'āshub, dan alwathaniyah, hanya berkisar masalah hak sebagai muslim, hak tetangga, dan sekitaran bahasan akhlak serta etika. Meskipun demikian, genealogi dan sanad pemahaman perdamaian dari Kiai Ali Maschan didapatkan dari pelajaran kitab Idhat al-Nasyi'in, Tafsir Munir, dan Kitab Mauidlatul Mu'minin yang beliau kaji di pesantren dahulu dan diajarkan pula di Pesantren Luhur Al-Husna sekarang. Juga, dari penelitian disertasi beliau yang berjudul "Agama dan Politik: Studi Konstruksi Sosial Kiai Tentang Nasionalisme Pasca Orde Baru (Moesa, 2006)."

Kenyataan yang terjadi, tidak ada kitab yang menerangkan tentang perdamaian secara spesifik. Kalaupun santri bersikap toleran dan damai, dikarenakan resepsi mereka atas apa yang di-dawuh-kan kiai serta pemahaman pada fasal-fasal adab di kitab tasawuf (Baca: Mauidlatul Mu'minin). Memang, ada satu kitab yang membahas tentang perdamaian, ialah kitab Al-Insaniyah Qabl al-Tadayun, karangan Ali Zainul Abidin Al-Jufri, diterbitkan di Tarim, Yaman pada tahun 2015. Namun, kitab ini tergolong kitab kontemporer yang eksistensi keberadaannya lebih akhir dibandingkan berdirinya Pesantren Luhur Al-Husna. Sehingga, ada atau tidak adanya kitab itu, penyemaian nilai perdamaian sudah berlangsung lama dilakukan oleh Kiai Ali Maschan dan asatidz yang lain sebelum kitab tersebut dikarang.

Lebih jauh selain verbalisasi, laku spiritual dan moral juga sangat berpengaruh dalam penyemaian nilai perdamaian. Aspek tersebut menjadi entitas hidup dalam dunia pesantren. Dan, termasuk dalam metode pendidikan yang diajarkan. Beberapa aspek tersebut tergambar dalam laku yang kurang masuk akal, sepert: mencium tangan kiai, meminum dan memakan sisa makanan dan minuman Kiai, adanya riyadlah, menunduk ketika bertemu, dan lain sebagainya. Aspek tersebut ditegaskan oleh Asror (2020) dan Izzuddin (2020), terletak pada konsepsi mengenai sebuah keberkahan -barokah, dan menjadi bernilai spiritual. Sedang dalam aspek moral, mencium tangan kiai memberikan pemahaman penghormatan kepada orang lain. Begitu pula menunduk ketika lewat di depan kiai, memberikan pemahaman untuk menghormati siapa saja yang telah mengajarinya. Praktik yang telah dijalankan tersebut akan menanamkan perilaku damai di tengah masyarakat, sebab, menghormati merupakan sifat yang bertentangan dengan kekerasan. Untungnya, hampir semua pesantren di Jawa Timur khususnya, menerapkan sikap seperti ini dalam kehidupan sehari-hari, termasuk Pesantren Luhur AlHusna. 


\section{Santri Al-Husna dalam Lingkaran Perdamaian}

Sebagai upaya partisipasi Pesantren Luhur Al-Husna dalam perdamaian nasional, dapat dilihat dan dideskripsikan dari beberapa kegiatan yang diselenggarakan dan/atau diikuti oleh para santrinya. Selain lewat jalur penanaman nilai perdamaian oleh Kiai Ali Maschan, ada beberapa kegiatan yang diikuti oleh santri, di antaranya: berperan aktif dalam Forum Kerukunan Umat Beragama (FKUB) kota Surabaya dan melakukan pertukaran pengetahuan (exchange) antar umat beragama. FKUB Surabaya merupakan sebuah wadah, tempat, atau lembaga yang disiapkan bagi persatuan umat dengan berbagai macam agama yang ada di Surabaya. Sebagai lembaga yang menaungi banyak agama, dapat dipastikan di dalamnya terdapat banyak perwakilan dari masing-masing agama dan menjadi representasi dari agamanya masing-masing. FKUB Surabaya mempunyai peran penting bagi adanya toleransi di Surabaya. Toleransi di atas dapat diterjemahkan sebagai sikap saling menghormati dan manghargai antar kelompok atau golongan, dan antar individu dalam satu golongan. Bukti bahwa santri terlibat dalam kegiatan yang diadakan FKUB Surabaya ialah, sebagaimana yang disampaikan oleh Ahmad Rudi tentang seringnya Kiai Ali Maschan menjadi pemateri seminar yang diadakan oleh FKUB Surabaya tersebut (Rudi, 2020; Kornus, 2018). Sedangkan para santri menjadi peserta ketika acara berlangsung baik ketika Kiai Ali Maschan menjadi pemateri atau tidak.

Ahmad Tazi lanjut menuturkan bahwa santri Al-Husna juga aktif di berbagai kegiatan bersama persatuan Gereja Protestan Indonesia Bagian Barat (GPIB) Surabaya, baik ketika bertempat di Pesantren Luhur Al-Husna atau di tempat lain. Salah satu contoh ialah diselenggarakanya kegiatan "Mondok Bareng" di Pesantren Luhur Al-Husna. Kegiatan ini diselenggarakan oleh pengurus pesantren bersama GPIB Surabaya dengan mendatangkan pemuda gereja untuk bermalam dan melihat kegiatan para santri di pesantren. Kegiatan ini berlangsung selama sehari dua malam, dari tanggal 14-15 September 2018. Tidak hanya mengamati kegiatan pesantren, para santri dan pemuda gereja juga melakukan dialog bersama, mulai dari kegiatan keseharian sampai pada tataran diskusi keagamaan. Dalam diskusi bersama, keduanya menghadirkan beberapa data sekitar kejadian intoleran dan dibahas mengenai faktor penyebab dan bagaimana cara menghadapinya. 
Diskusi berlangsung dua jam dan diakhiri dengan sama-sama berdoa dengan kepercayaan masing-masing. Keesokan harinya, selepas Shubuh, pemuda gereja mengikuti kegiatan ngaji kitab tafsir yang diampu oleh Kiai Ali Maschan (Tazi, 2020; Maulana and Nawawi, 2018). Selain kegiatan mondok bareng yang dilaksanakan di pesantren, pada kesempatan yang lain santri AlHusna juga menghadiri acara yang diselenggarakan oleh GPIB Surabaya, yakni ketika peringatan hari jadi GPIB Surabaya ke-70 yang dilaksanakan di Hotel Veni Vidi Vici (V3) Hotel Surabaya. Kedatangan santri Al-Husna dalam acara ini selain sebagai tamu undangan, juga sebagai pengisi acara. Para santri membawakan pesembahan berupa nyanyian selawat dan mars hubbul wathan dengan iringan banjari -terbang. Acara ini dilaksanakan pada 6 November 2018. Selanjutnya, pada tanggal 25 Desember 2019, santri Al-Husna mendapatkan undangan untuk menghadiri natalan bareng di GPIB Jemaat Benowo Surabaya. Dua hari berikutnya, masih dalam perayaan yang sama, santri Al-Husna mendapatkan undangan dari GPIB Jemaat Genta Kasih Rungkut Surabaya.

Tidak hanya itu, Himam (2020), Subhan (2020), Salimuddin (2020), dan Wicaksono (2020), kesemuanya merupakan santri Al-Husna yang aktif mengikuti kegiatan Bord Game For Peace -BGFP. BGFP merupakan sebuah tranining/pelatihan membuat dan menggunakan permainan papan sebagai sarana perdamaian. Permainan papan tersebut sekilas mirip dengan permainan monopoli atau permainan ular tangga. Acara ini dinisiasi dan diselenggarakan oleh Peacegen.id. Dan, berlangsung dua kali kegiatan, untuk yang pertama diikuti oleh Ahmad Himam dan Yusril Salimuddin pada tanggal 21-22 April 2017, sedangkan yang kedua diikuti oleh Muhammad Subhan dan Anggar Wicaksono pada tanggal 02-04 September 2018. Selanjutnya Achmad Ma'ruf Islamudin juga pernah mengkuti kegiatan yang diselenggarakan oleh Global Peace Fondation. Acara ini bertujuan untuk memahami kultur masingmasing pemeluk agama dengan berkunjung ke tempat ibadah masing-masing. Berlangsung pada tanggal 27-28 Oktober 2018 (Islamudin 2020).

Santri Al-Husna juga aktif menjadi pengurus pada organisasi perdamaian. Mohammad Iqbal misalnya, ia aktif dalam struktur pengurus Gusdurian Jawa Timur dan pengurus Youth Interfaith Peace Center (YIPC) Jawa Timur (Iqbal, 2020). Sedangkan Davida Ruston Khusen aktif menjadi pengurus Wahid Foundation bagian Officer Media dan Kampanye (Foundation, 2020). Sebagaimana yang telah disampaikan oleh Iqbal dan Kholili, bahwa penyemaian perdamaian yang dilakukan oleh Kiai Ali Maschan banyak lewat 
jalur verbalisasi, hal ini yang menjadikan para santri masif berpartisipasi dalam kegiatan dan ritus perdamaian. Pemahaman santri tentang perdamaian merupakan asimilasi dan akulturasi dari budaya pesantren di mana santri tinggal. Santri akan cenderung mengikuti kianya dalam segala hal dikarenakan dalam diri manusia terdapat fitrah al-nafsiyah dengan sistim quwwah al-fikr - daya kognisi. Lingkungan pesantren yang terdiri dari banyak individu akan saling mempengaruhi satu sama lain, baik secara alloplastis atau autoplasstis. Pergaulan nantinya akan membentuk suatu komunitas, yang mana komunitas dalam pandangan Islam disebut dengan kaum, yang seakar dengan bangsa, dan sepadan dengan umat (Sudjatnika, 2016).

Lebih lanjut jika ditinjau dalam segi konstruksi sosial, Berger dan Luckman (1991) berpendapat bahwa institusi manusia dipertahankan dan dibentuk berdasarkan interaksi manusia di dalamnya. Meskipun komunitas dan institusi sosial nyata terbentuk dan terlihat secara obyektif, namun di dalamnya dibangun antar subjektifitas anggota komunitas melalui proses interaksi. Obyektifitas baru bisa terlihat dari subjektifitas kelompok yang memiliki definisi yang sama. Sehingga, manusia melegitimasi makna yang universal untuk mengatur kehidupan sosial dan memberikan makna di dalamnya (Manuaba, 2008). Pandangan tersebut jika dikaitkan dengan sikap pluralisme dan perdamaian nasional santri Al-Husna, maka akan terjadi fenomena masing-masing orang mempunyai kepercayaan dan pandangan pluralitas serta perdamaian. Pandangan tersebut kemudian ditegaskan oleh banyak santri secara berulang, lanjut melahirkan dunia secara simbolis yakni melaksanakan dan berpartisipasi dalam kegiatan atau organisasi perdamaian.

Selain itu juga, pandangan pluralisme dan perdamaian nasional santri Al-Husna berlangsung dalam suatu proses dengan tiga momen simultan, yaitu eksternalisasi, objektivikasi, dan internalisasi. 1). Eksternalisasi, yakni proses penyesuaian diri dengan dunia sosio-kultural produk manusia. 2). Objektivikasi, yakni interaksi sosial yang terjadi dalam dunia intersubjektif yang disusun atau mengalami institusionalisasi. 3). Internalisasi, yakni proses individu mengidentifikasi dirinya dengan lembaga-lembaga sosial atau organisasi sosial tempat individu menjadi anggotanya (Ngangi, 2011).

Penerimaan pemahaman santri mengenai pluralitas dan perdamaian nasional tergambar dari banyak laku atau partisipasi mereka dalam pelbagai aktivitas yang dilakukan di ruang budaya -cultural space- yang diciptakan, dalam hal ini berupa dialog dan seminar dalam FKUB, menghadiri acara GPIB, bertempat tinggal serta menyediakan tempat tinggal bagi pemeluk agama lain 
(live in) dan menjadi pengurus organisasi perdamaian. Banyaknya santri yang tergabung dan mengikuti fotum-forum yang berlebel "Toleransi," FKUB, GPIB, YIPC, dan seterusnya menunjukkan penerimaan santri terhadap tradisi dan relasi umat antar agama. Dengan demikian, adanya partisipasi dari kesemua agama, termasuk para santri, menandakan adanya penerimaan mereka terhadap nilai dan tindakan tersebut. Namun, tidak sedikit pula elit agama dan santri konservatif yang menolak kegiatan doa bersama, dialog bersama, dan seremonial keagamaan. Penolakan tersebut berasal dari intepretasi dan pemahaman teks agama yang berbeda. Bentuk penolakan tersebut tergambar dari pernyataan mereka bahwa paham puralisme berasal dari pemahaman yang diintrodusir dari Barat dan lahir dari rahim liberalisme yang menyesatkan. Umumnya, mereka dari golongan Islam kanan. Penolakan kepada pluralisme, mengakibatkan penolakan mereka terhadap doa bersama, live in, dialog, dan partisipasi dalam kepengurusan organisasi perdamaian.

Terlepas dari penolakan yang diluncurkan, banyak santri yang menganggap bahwa Kiai Ali Maschan merupakan sosok yang berperan, juga berpengaruh pada pembentukan pola pikir dan tindakan pluralisme serta perdamaian. Wardhana (2020), Anam (2020), Izzuddin(2020), dan Andi AlFarisi menuturkan, bahwa Kiai Ali Maschan merupakan sosok yang sederhana dengan pemahaman perdamaian yang menetramkan, mencintai bukan memusuhi, merangkul bukan memukul, dan berdakwah dengan ramah bukan amarah. Santri Al-Husna akan mengikuti pendapat kianya, yakni Kiai Ali Maschan. Beliau merupakan figur dan tokoh yang dianut serta dijadikan referensi.

Sejak isu pluralisme menguat di dunia Barat, khususnya di dalam agama Kristen, dan kebutuhan akan perdamaian yang dieksternalisasi harus dipenuhi, sejak saat itulah pluralisme dan perdamaian telah menjadi menu sehari-hari. Berbicara tentang pluralisme dan perdamaian sama halnya berbicara tentang agama itu sendiri. Karena pluralisme agama menjadi fenomena yang tergambar nyata. Bahkan para santri menganggap bahwa pluralitas dan perdamaian sudah menjadi pengetahuan dan realitas sosial. Sama halnya dengan sosialisasi prularisme dan perdamaian, harus beriringan dengan sosialisasi agama itu sendiri.

Paham prularitas dan perdamaian terus diinternalisasikan oleh para santri, sehingga menjadi realitas subjektif. Dan, realitas subjektif terus diinternalisasi dalam keseharian hidup. Karena memang pluralitas memiliki makna yang luas, dalam hal ini berakibat pada keragaman eksternalisasi yang 
dijalankan santri, bisa dengan wujud kegiatan sampai pada partisipasi dalam sebuah kepengurusan. Tak pelak, prulalisme memiliki kenyataan objektif yang tak bisa dinafikan bagi para santri yang puritan. Namun di sisi lain, pluralisme adalah kenyataan subjektif -yang relatif dan dinamis. Pluralisme bisa menjadi nyata bagi sebagian orang, tetapi bisa tidak menjadi nyata bagi sebagian yang lain. Dengan demikian, pluralisme memiliki keragaman makna subjektif, masing-masing individu memiliki penafsiran sendiri-sendiri, dan penafsiran (makna subjektif) tersebut terus berproses sepanjang waktu (dinamis).

Pesantren Luhur Al-Husna merupakan jalur sosialisasi dan media sosialisasi yang efektif bagi pembentukan pola pemikiran pluralitas. Disini, santri akan lebih mudah untuk diidentifikasi berdasarkan atas apa yang dilakukan dalam kesehariannya dan dalam interaksinya dengan dunia di sekelilingnya. Dengan demikian, bagi santri yang memiliki alur pemikiran moderat dan plural cenderung akan mengikuti pola pemikiran kianya, kiai Ali Maschan, dan begitu seterusnya. Ujung akhir dari identifikasi tersebut ialah penamaan spontanitas bagi nama lain Pesantren Luhur Al-Husna sebagai pesantren perdamaian.

Dari apa yang dilakukan oleh santri tentang pelaksanaan kegiatan dan menjadi pengurus organisasi perdamaian, terinspirasi dari Kiai Ali Maschan yang memberikan pemahaman sekaligus teladan. Di mana kiai Ali Maschan selalu mengulang-ulang dalam penanaman pluralisme dan perdamaian. Pengamatan tersebut menjadi objektifikasi, dan secara tidak sadar menginternalisasi dalam perilaku santri. Sedangkan aspek eksternalisasi didapati melalui pemahaman mengenai pluralisme dan perdamaian yang dijelaskan oleh para ustadz, lebih-lebih kiai Ali Maschan. Adapun hasil dari proses internalisasi, yakni memahami dan menjalankan pluralitas dan perdamaian beragama di Indonesia dalam bentuk pelaksanaan kegiatan dan menjadi pengurus organisasi perdamaian. Sebagaimana diketahui dalam ajaran Islam, pluralitas adalah sebuah keniscayaan atau sunnahtullah, "Wahai manusia, sungguh, Kami telah menciptakan kamu dari seorang laki-laki dan seorang perempuan, kemudian Kami jadikan kamu berbangsa-bangsa dan bersuku-suku untuk saling mengenal." (QS: 43:13) Dalam konteks tersebut telah jelas bahwa pluralitas adalah realitas sosial yang tidak bisa dihindarkan. Dengan demikian membangun perdamaian adalah sebuah keharusan bagi seluruh elemen yang ada di masyarakat, khususnya pesantren sebagai lembaga pendidikan Islam yang menebarkan nilai-nilai rahmatan lil'alamin.yaitu rahmat bagi alam semesta. 


\section{Simpulan}

Sebagai kata penutup, dapat disimpulkan bahwa Pesantren Luhur AlHusna mempunyai peranan besar dalam perdamaian nasional. Dalam menanamkan nilai perdamaian Pesantren Luhur Al-Husna mempunya dua arah: yakni, melalui dawuh dari Kiai Ali Maschan dan melalui etika pembiasaan pesantren. Kedua hal tersebut menjadi bagian daripada verbalisasi. Sedangkan ajaran kitab kuning, mempunyai pengaruh atau peranan sekunder bagi penanaman nilai perdamaian santri Al-Husna. Dua hal tersebut merupakan aspek eksternal di pesantren yang dipahami dan diobjektifikasi menjadi sebuah kebenaran umum, bahwa Pesantren Luhur Al-Husna ialah pesantren "Perdamaian." Kemudian nilai perdamaian terinternalisasi dalam moral dan laku yang berujung pada kegiatan dan pengambilan peran dalam organisasi dan kelompok perdamaian. Penelitian ini masih terbatas pada peran keterlibatan pesantren dalam organisasi atau kelompok perdamaian yang ada di masyarakat, belum meneliti pada aktivias program yang dilakukan. Oleh karenanya perlu adanya penelitian lanjutan untuk melengkapi penelitian ini.

\section{Referensi}

Al-Amanah. (2021). Profil Pesantren Al-Amanah Junwangi. http://www.pmacollege.sch.id/detailpost/profil-pesantren-modern-al-amanah

Al-Madinah. (n.d.). Pusat Pelatihan Kewirausahaan Untuk Yatim Dan Dhuafa Pertama di Indonesia. http://yas.rf.gd/

Anam, N. (2018). Pembelajaran Pendidikan Karakter dalam Konteks Tasawuf IrfaniAkhlaqi. Jurnal Al-Wijdan, 3(2).

Asror, S. (2020). Peran Kiai dalam Membangun Nasionalisme (Studi Pemikiran dan Peran KH. Ali Maschan Moesa dalam Membangun Nasionalisme di Pesantren Luhur AlHusna dan Jemaat Gereja Protestan di Indonesia Bagian Barat Surabaya). Universitas Islam Negeri Sunan Ampel Surabaya.

Barton, G. (2004). Biografi Gus Dur. LKiS.

Berger, P. L., \& Luckman, T. (1991). The Social Construction of Reality. Penguin Books.

Bruinessen, M. van. (1994). Pesantren and Kitab Kuning: Maintenance and Continuation of a Tradition of Religious Learning. University of Berne.

Dhofier, Z. (2011). Tradisi Pesantren Studi Pandangan Hidup Kyai dan Visinya Mengenai Masa Depan Indonesia. LP3ES.

Geertz, C. (1992). Kebudayaan Dan Agama. Kanisius.

Hamid, A. (2017). Pendidikan Karakter Berbasis Pesantren: Pelajar dan Santri Dalam Era IT \& Cyber Culture. Imtiyaz.

Hilmy, M. (2019). Kepemimpinan Modern Berbasis Karakter Pesantren. Jurnal 
Pendidikan Agama Islam (Journal of Islamic Education Studies). https://doi.org/10.15642/jpai.2019.7.2.89-109

Indonesia, K. A. P. K. K. B. L. dan D. R. (2012). Dinamika Sistem Keagamaan Lokal Di Indonesia. Badan Litbang dan Diklat Kementerian Agama RI.

Kusumo, E. S. (2015). Bentuk Sinkretisme Islam-Jawa di Masjid Sunan Ampel Surabaya. Mozaik, 15(1), 17.

Mambaul Falah. (n.d.). Yayasan Pendidikan Mambaul Falah. https://manbaulfalah.or.id/?ga_action=googleanalytics_get_script

Manuaba, I. B. P. (2008). Memahami Teori Konstruksi Sosial. Masyarakat, Kebudayaan dan Politik, 21(3), 11.

McLeod, J. (2001). Qualitative Research in Counselling and Psychotherapy. SAGE.

Moesa, A. M. (2006). Agama Dan Politik Studi Konstruksi Sosial Kiai Tentang Nasionalisme Pasca Orde Baru. Airlangga Surabaya.

Moleong, L. J. (2015). Metode Peneltian Kualitatif. Remaja Rosdakarya.

Muhakamurrohman, A. (2014). Pesantren: Santri, Kiai, Dan Tradisi 12 (2): 109-18. IBDA`: Jurnal Kajian Islam dan Budaya: Jurnal Kajian Islam dan Budaya, 12(2), 109118. https://doi.org/10.24090/ibda.v12i2.440

Ngangi, C. R. (2011). Konstruksi Sosial dalam Realitas Sosial. AGRI-SOSIOEKONOMI, 7(2), 1. https://doi.org/doi.org/10.35791/agrsosek.7.2.2011.85

Ningrum, D. J., Suryadi, \& Wardhana, D. E. C. (2018). Kajian Ujaran Kebencian di Media Sosial. Jurnal Ilmiah Korpus, 2(3), 241-1252. https://doi.org/https://doi.org/10.33369/jik.v2i3.6779

Pengurus. (n.d.). Visi-Misi Pesantren Luhur Al-Husna. Pesanten Luhur Al-Husna.

Qurani, P. (n.d.). Pesantren Entrepreneuer Qurani Bandung.

Rofiq, A. (2018). Sowan dan Penguatan Pendidikan Karakter Pesantren Berkelanjutan. Ta'allum: Jurnal Pendidikan Islam, 6(2), 241-258. https://doi.org/https://doi.org/10.21274/taalum.2018.6.2.241-258

Sidiq, U. (2013). Pengembangan Standarisasi Pondok Pesantren. Nadwa, 7(1), 71. https://doi.org/https://doi.org/10.21580/nw.2013.7.1.544

Sudjatnika, T. (2016). Tinjauan Kognisi Sosial Terhadap Sosial Budaya. Al-Tsaqafa: Jurnal Ilmiah Peradaban Islam, 13(1), 159-176. https://doi.org/https://doi.org/10.15575/al-tsaqafa.v13i01.1839

Usman, M. I. (2013). Pesantren Sebagai Lembaga Pendidikan Islam (Sejarah Lahir, Sistem Pendidikan, dan Perkembangannya Masa Kini. Al Hikmah, XIV(1), 101-119.

Yuwafik, M., \& Muhid, A. (2020). Strategi Dakwah Pesantren Luhur Al-Husna Dalam Menjaga Toleransi Beragama Di Kota Surabaya. MUHARRIK: Jurnal Dakwah dan Sosial, 3(2), 195-211. https://doi.org/https://doi.org/10.37680/muharrik.v3io2.431 
This page intentionally left blank 